\title{
The Spatial and Temporal Characteristics of Rainfall over the Lake Victoria Basin of Kenya in 1987-2016
}

\author{
Wabwire Odhiambo Evans ${ }^{1}$, S. N. Mukhovi2, I. A. Nyandega ${ }^{2}$ \\ ${ }^{1}$ Catholic University of Eastern Africa, Nairobi, Kenya \\ ${ }^{2}$ University of Nairobi Kenya, Nairobi, Kenya \\ Email: ewabwire@cuea.edu
}

How to cite this paper: Evans, W.O., Mukhovi, S.N. and Nyandega, I.A. (2020) The Spatial and Temporal Characteristics of Rainfall over the Lake Victoria Basin of Kenya in 1987-2016. Atmospheric and Climate Sciences, 10, 240-257.

https://doi.org/10.4236/acs.2020.102013

Received: March 3, 2020

Accepted: April 24, 2020

Published: April 27, 2020

Copyright $\odot 2020$ by author(s) and Scientific Research Publishing Inc. This work is licensed under the Creative Commons Attribution International License (CC BY 4.0).

http://creativecommons.org/licenses/by/4.0/

\begin{abstract}
Climate extremes have increased in the recent past and they are further being exacerbated by climate change and variability. In this paper, we sought to determine rainfall characteristics over the Lake Victoria Basin of Kenya in 1987-2016, as a basis of understanding climate variability. The methodology used included; Standardized Precipitation Index to depict variability, coefficient of variation for spatial analysis and the Mann-Kendall test to test the presence of trends in data. We established that Lake Victoria basin is relatively wet through-out the year, with two distinct rainfall seasons March-April-May (MAM) and October-November-December (OND) that support human livelihood and ecology. The normal wetness conditions have declined over time, paving way for both dry and wet extremes conditions between 1997-1998 and 2002-2006, respectively. The rainfall extremes have become frequent in the last decade in 2007-2016. We also established a decline in the MAM rainfall seasons, and an increase during the October-December rainfall seasons in 1987-2016. Furthermore, the number of rainy days has declined with the onset and cessations of both long rains and short rains having shown a variability of at least $50 \%$ and $30 \%$ respectively, in a range of about 100 to 200 Julian days. The decline in wet condition is likely to affect economic activities especially the rainfed agriculture. The changing rainfall trends over the basin therefore, call for proper human livelihood planning and ecological monitoring in order to achieve ecological sustainability.
\end{abstract}

\section{Keywords}

Climate Variability, Seasonal Rainfall, Intra-Seasonal Rainfall Characteritics and Lake Victoria Basin 


\section{Introduction}

Rainfall plays an important role in the social and economic activities of the residents of the Lake Victoria Basin of Kenya [1]. Agriculture for instance, which accounts for $80 \%$ human labour in the region is largely rainfed [2]. Rainfall therefore is an important weather element within the Basin; as it controls most of the climate-sensitive activities done in most households in the region. Over the years, rainfall in the East Africa region has fluctuated, with no substantive research showing a clear trend. Climate change and variability has further, imposed changes in rainfall patterns, making it difficult to understand and predict the general patterns of precipitations extremes [3] [4]. While there exists a strong interest among many researchers on understanding the climate system in the face of climate change [5] [6] [7], information on the spatial and temporal variability of climate over the Lake Victoria Basin is still limited. Previous studies in the LVB have shown that understanding and predicting the complex climate system through simulation is a daunting task stemming from the lack of accuracy of climate models used [8] [9] [10]. The basin is also characterized by a complex climate system which is difficult to simulate due to undulating terrain and interaction of the inter-tropical convergence zone (ITCZ). In the present paper, the rainfall variability was investigated to catch a glimpse of climate variability in the LVB of Kenya. Considerable success in such a study has been documented [11] [12]. Understanding the rainfall dynamics within the LVB, therefore, remains a relevant topic that requires urgent attention.

\subsection{Climate of Lake Victoria Basin}

The LVB of Kenya experiences a range of climates, from a modified equatorial found in highland areas to semi-arid condition close to the Lake Victoria. The area generally receives a bimodal distributed rainfall, which is attributed to the occurrence of the low atmospheric pressure belt caused by the Inter-Tropical Convergence Zone (ITCZ), which crosses the equator twice a year [13] [14]. Rainfall is an important weather element in the Lake Victoria Basin; it controls most of the climate-sensitive activities of most households in the area. The Congo airstream, westerlies and monsoons have a direct effect on the rainfall. The monsoons, for instance, accounts for arid conditions around the lake since they are thermally stable, while the Congo air mass accounts for rainfall in the lake vicinity since it is unstable and significantly increases convection activities [15]. Annual rainfall varies from 700 to $2000 \mathrm{~mm}$. There is a poor distribution of rainfall within the lower regions bordering the lake, which has very low rainfall while highland has higher rainfall. Maximum temperatures in the region range between $28.6^{\circ} \mathrm{C}$ and $28.7^{\circ} \mathrm{C}$, while the minimum varies from $14.7^{\circ} \mathrm{C}$ to $18.2^{\circ} \mathrm{C}$. The LVB of Kenya has five major drainage rivers: Nyando, Nzoia, Sio, Sondu, and Yala, which form an elaborative drainage pattern as shown in Figure 2. All of these rivers rise from the Rift Valley and the western highlands. The river regime in the basin is predominantly determined by the rainfall distribution. 
Attempts to understand the climate trends in the entire LVB [16] [17] [18], have exposed extreme rainfall events such as above normal and below normal rainfall, which correlated with the El Nino-Southern Oscillation (ENSO) and La Nina, respectively [19]. Other seasonal changes earlier observed across East Africa, included delayed onsets and fast cessations of long rains prolonged and intensified droughts [20], all of which have an impact on the climate of the Lake Victoria ecosystem [21].

The Lake Victoria ecosystem plays important roles; it provides human livelihoods, it is a rich lifeline for flora and fauna and water resources that are dependent on the climate. Unfortunately, rainfall has become one of the most elusive meteorological elements to predict. Existing literature shows a significant change in climate [22] [23]. The intensity and frequency of rainfall in some areas have increased while other areas' temperatures have increased, more especially in the Sahel region [24].

\subsection{Relief of Lake Victoria Basin of Kenya}

Lake Victoria Basin is characterized by a heterogeneous pattern of landscapes, with the plains bordering Lake Victoria being affected by floods. The area generally slopes toward Lake Victoria. There are hills such as Samia, Bunyore, and Homa and Gwasi ranges in the LVB. There are also other relief features such as Mt. Elgon and escarpments near the Rift Valley, which, together with its altitude ranges of between 1800 to 3000 meters above sea level have generally affected the rainfall distribution and moderated the temperature experienced within the basin. General relief and drainage of the basin predispose the population to almost yearly flood risks in their lower regions, thus causing major damages to their livelihoods.

\subsection{Area of Study}

The Lake Victoria Basin of Kenya is found within latitudes $1^{\circ} 15^{\prime}$ North and $1^{\circ} 30^{\prime}$ South and longitudes $34^{\circ}$ East and $35^{\circ} 30^{\prime}$ East. Consequently, LVB is located within the equatorial region. It is an expansive geographical area stretching from the Mau Ranges to the border of Uganda and Tanzania (Figure 1). The area is approximately $38,913 \mathrm{~km}^{2}$, which accounts for $21.5 \%$ of the total area of the entire basin, with a shoreline of about $550 \mathrm{~km}$ [25]. The Basin is characterized by a heterogeneous pattern of landscapes. The soils found in the LVB are largely derived from a complex Kavirondian and the Nyanza rock systems, which are the oldest rocks in the region.

\section{Data \& Methods}

Both gridded and station observation datasets were used in the analysis. The station dataset was obtained from Kenya Meteorological Department headquarters at Dagoreti, Nairobi (Table 1), while the gridded data were those from Climate Research Unit (CRU). Both data necessary to ensure the credibility of the results. 

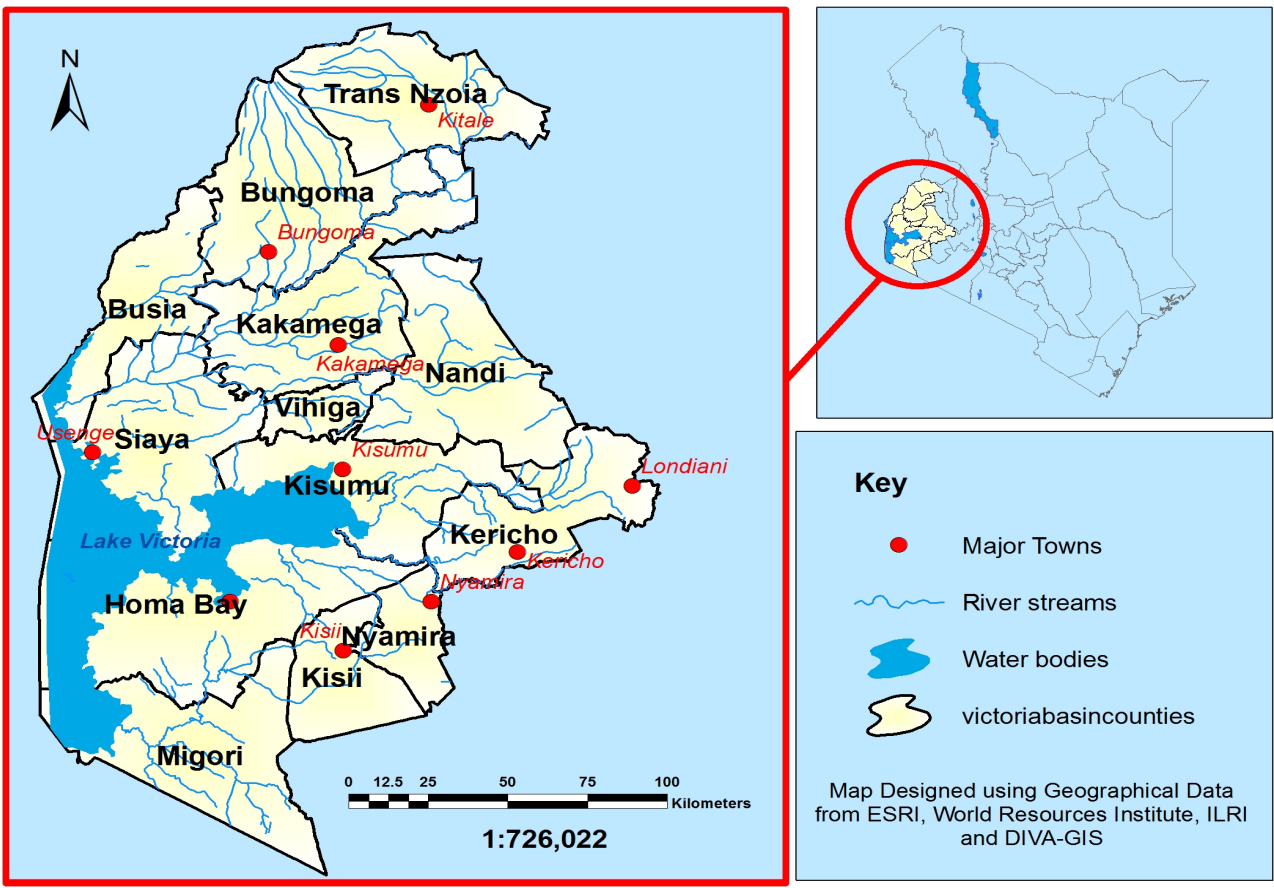

Figure 1. The Lake Victoria Basin of Kenya (Source: Survey of Kenya, 2017).

Table 1. Selected weather stations in LVB.

\begin{tabular}{ccccccc}
\hline No & Number & Name of weather station & Latitude & Longitude & Altitude & $\begin{array}{c}\text { Observation } \\
\text { period }\end{array}$ \\
\hline 1. & 9034025 & Kisumu Meteorological Station & -0.1 & 34.75 & 1130.7 & $1987-2016$ \\
2. & 8933026 & Port Victoria Catholic Mission & 0.12 & 33.98 & 1230 & $1987-2016$ \\
3. & 8934096 & Kakamega Agromet Station & 0.28 & 34.77 & 1530 & $1987-2016$ \\
4. & 8934106 & Bukembe & 0.62 & 34.67 & 1438 & $1987-2016$ \\
5. & 8934098 & Kimilili Forest Station & 0.87 & 34.68 & 1650 & $1987-2016$ \\
6. & 8834098 & Kitale Meteorological Station & 1.02 & 34.98 & 1875 & $1987-2016$ \\
7. & 9034088 & Kisii Meteorological Station & -0.68 & 34.78 & 1740 & $1987-2016$ \\
8. & 8935010 & Kaptagat Forest Station & 0.43 & 35.50 & 2200 & $1987-2016$ \\
9. & 8934016 & Lugari Forest Station & 0.66 & 34.90 & 1590 & $1987-2016$ \\
10. & 8934061 & Malava Agric. Station. & 0.45 & 34.85 & 1560 & $1987-2016$ \\
11. & 8934023 & Sang'alo Institute Station & 0.53 & 34.58 & 1372 & $1987-2016$ \\
12. & 9035003 & Kericho Meteorological Station & -0.383 & 35.28 & 2184 & $1987-2016$ \\
13. & 9035229 & Sabatia Forest Station & -0.05 & 35.75 & 1740 & $1987-2016$ \\
14. & 9134009 & Muhuru Bay Hydromet. Station & 0.99 & 34.09 & 1200 & $1987-2016$ \\
\hline
\end{tabular}

(Sources: Kenya Meteorological Department, 2017).

\subsection{Observation Data}

Kenya Meteorological Department observation data had some missing data due to meteorological logistics as well as low-density station network. For the purpose of this study, fourteen weather stations with a 30-year climatological peri- 
od, with monthly accumulative data were used as recommended by the WMO (Table 1). The gaps in the observation data made the use of this data complex. The observed data were first subjected to quality control and homogeneity test [26] [27] to ensure credible information. Two quality control checks were run to ensure consistency, reliability, and validity of data before being used for this study. First, the error checks were performed using an ISTAT+ version V3.36. Weather stations that had more than $10 \%$ missing data were not used in this study, while, for stations that had less than $10 \%$ of missing data, the statistical mean was computed and then used to estimate the missing values in data that had no extreme values. In cases with extreme values, the median was used in order to establish a good representation of the data.

\subsection{Climatic Research Unit Data (CRU)}

Climatic Research Unit Data used in this study was for the period in 1981-2016. The Climatic Research Unit is a climate research unit in England at the University of East Anglia. The research unit focuses on and studies natural and anthropogenic climate change. The data was retrieved in a monthly period within the same grids of the weather station data sources using the interpolation method at different precision of $0.5,1.5,2.0,2.5$. The estimation used to solve missing data is estimated from the reference period 1971-2016.

\subsection{Methods}

The methodology used in this study included first subjecting the data to seasonal, monthly and annual analysis to explore the rainfall trends over the LVB. We first analyzed the annual rainfall distribution using the climatological monthly mean plots for all the selected weather stations to reveal the rainfall regimes over the basin. We then carried out the trend analysis using long term monthly mean rainfall. It was important for us to establish the existence of trends since they were likely to affect the means, standard deviation, or any other aspects of time series that were important in determining wetness and dryness. We used R-Language and Environment for Statistical Computing software to generate the scripts for data manipulation, calculation of estimates and graphical representation. The benefits of using this software are well documented ( $\mathrm{R}$ core Team, 2018) [28].

We determined the extent of wetness and drought by using Standardized Precipitation Index (SPI) for the period between 1987 and 2016, and presented the result as a proportion of the whole region. We analyzed the SPI index at three months and twelve-month scale and the reference for the results was based on WMO SPI [29] to depict climate variability/change. The two scales were considered important since they greatly affect rain-fed agriculture, which is predominantly practiced in the area. The three-month scale, which is considered a shorter the timescale was much applicable to this study when considering the soil moisture content, while the twelve months' scale was significant in understanding its effect on rural livelihoods. 
The Co-efficient of Variation and mean distribution of both rainfalls were used for spatial analysis. We analyzed the coefficient of variation for all the seasons while we also applied the Mann-Kendall test to test the presence of trends in data. We determined the overall trends using the total annual rainfall and an annual the number of rainy days.

We used the method of Liebmann et al. (2012) [30] to determine the rainfall onset and cessation, where first the accumulative daily rainfall anomaly on a particular day we computed using the equation below:

$$
C(d)=\sum_{j=1 \text { jan }}^{d} Q_{i}-\bar{Q}
$$

where:

$C(d)$ was accumulative daily rainfall anomaly, $Q_{i}$ was the calendar year ranging from $1^{\text {st }}$ January to $31^{\text {st }}$ December and, $Q$ was the climatological mean rainfall, $i$ ranged from $1^{\text {st }}$ January to day $(d)$ for which commuting applied.

Then onsets and cessations dates we computed individually for each year using the equation below:

$$
A(D)=\sum_{j=d_{s} 1-20}^{d} R_{j}-\bar{Q}
$$

where:

$A(D)$ is the daily cumulative rainfall, $R_{j}$ is the rainfall on the day $j$ and $j$ ranged forms $\mathrm{d}_{\mathrm{s}}-20$. $A(D)$ was computed for each day $d_{s}-20$ to $d_{e}+20$ and for each year $d_{s 2}-20$ to $d_{e 2}+20$. The day after the minimum $A(D)$ was considered an onset date, while the maximum that occurred after was considered a cessation date for both seasons.

In addition, detection methods such as the optimal fingerprinting were applied in order to quantify climate change signals in light of internal climate variability. Using the standard deviation, the tendency towards exceptional events was checked at $95 \%$ confidence limit; at two standard deviations and any that fall outside \pm 2 standard deviations were considered exceptional.

\section{Results and Discussion}

\subsection{Lake Victoria Basin of Kenya Climatological Rainfall Using CRU Data}

Analysis of rainfall climatology over the period 1987-2016 in the LVB of Kenya (Figure 2) shows rainfall being recorded throughout the year. There are four distinct rainfall regimes; Jan-Feb (JB) though dry in most of the area, Mar-May (MAM), Jun-Sep (JJAS), and Oct-Dec (OND) seasons). These results are consistent with the work of [31] [32]. The climatological rainfall indicated some double maxima, which form a binomial rainfall; the first being March-April-May (MAM) for long rains, and October-November-December (OND) for short rains with the peaks in April and November respectively. The results of this work revealed a declining trend in MAM (long rains) and an increasing trend in the OND (short rains) rains in recent times. The results further indicated a weak correlation between MAM and OND rains, thus dispelling the suggestion that 


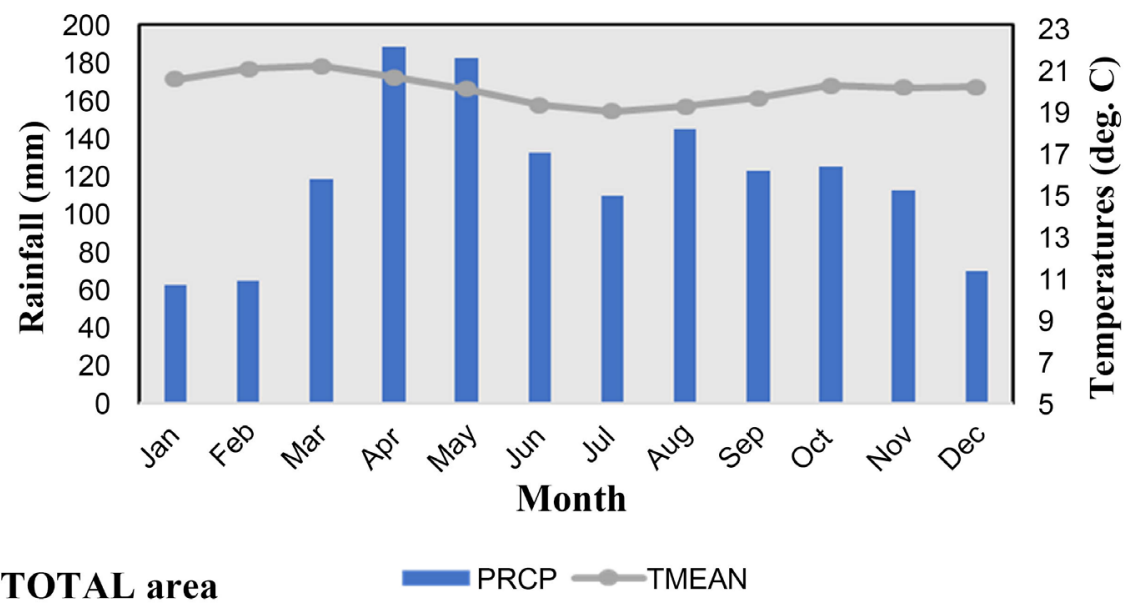

Figure 2. The mean monthly climatology of rainfall and mean air temperatures for entire Lake Victoria Basin of Kenya with baseline period of 1987-2016.

the decline of MAM rains could be the cause of the increase in OND rains. A strong correlation was however established between seasonal rains, the number of rainy days, and onsets and cessation of both MAM and OND rains (Figure 3).

\subsection{Analysis of Wetness and Dryness Condition over the Lake Victoria Basin of Kenya}

From the results in Figure 4(a) extremely wet rainfall conditions were recorded between 1997 and 1998 in the LVB, which coincided with the El Nino Southern Oscillation (ENSO) episode in Eastern Africa. In the decade between 2006 and 2016, these results are also reflected, with very wet rainfall conditions. The extremely dry conditions were centered around the years 2003-2005. On the SPI three-month scale the ENSO episode significantly represented (Figure 4(a)), however, it was suppressed under the 12 months' scale (Figure 4(b)). The return of extremely wet category rain was recorded between 2011 and 2016. The years between 2002 and 2006 exhibited extremely dry conditions on a 3-month SPI scale while on a 12-month scale same conditions were observed between 2004 and 2007 (Figure 4(b)). The results revealed that wet conditions have increased, while dry conditions have not significantly changed. The near-normal wet conditions in the LVB have shown a decline in the recent period as shown on both SPI scales (Figure 4(a) \& Figure 4(b)).

\subsection{The Rainfall Distribution in the Lake Victoria Basin of Kenya}

The seasonal trend analysis for all selected stations revealed changing patterns in rainfall over the basin for two successive climate regimes-they are compared here, as from 1957 to 1986 versus the most recent 1987 to 2016 climate period. The results from five weather stations, Muhuru Bay Hydromet Station (Figure 5), Kericho Meteorological Station (Figure 6), Kakamega Meteorological Station (Figure 7), Kisumu Meteorological Stations (Figure 8), and Kisii Meteorological Station (Figure 9) revealed a declining trend in MAM (long rains) seasonal 


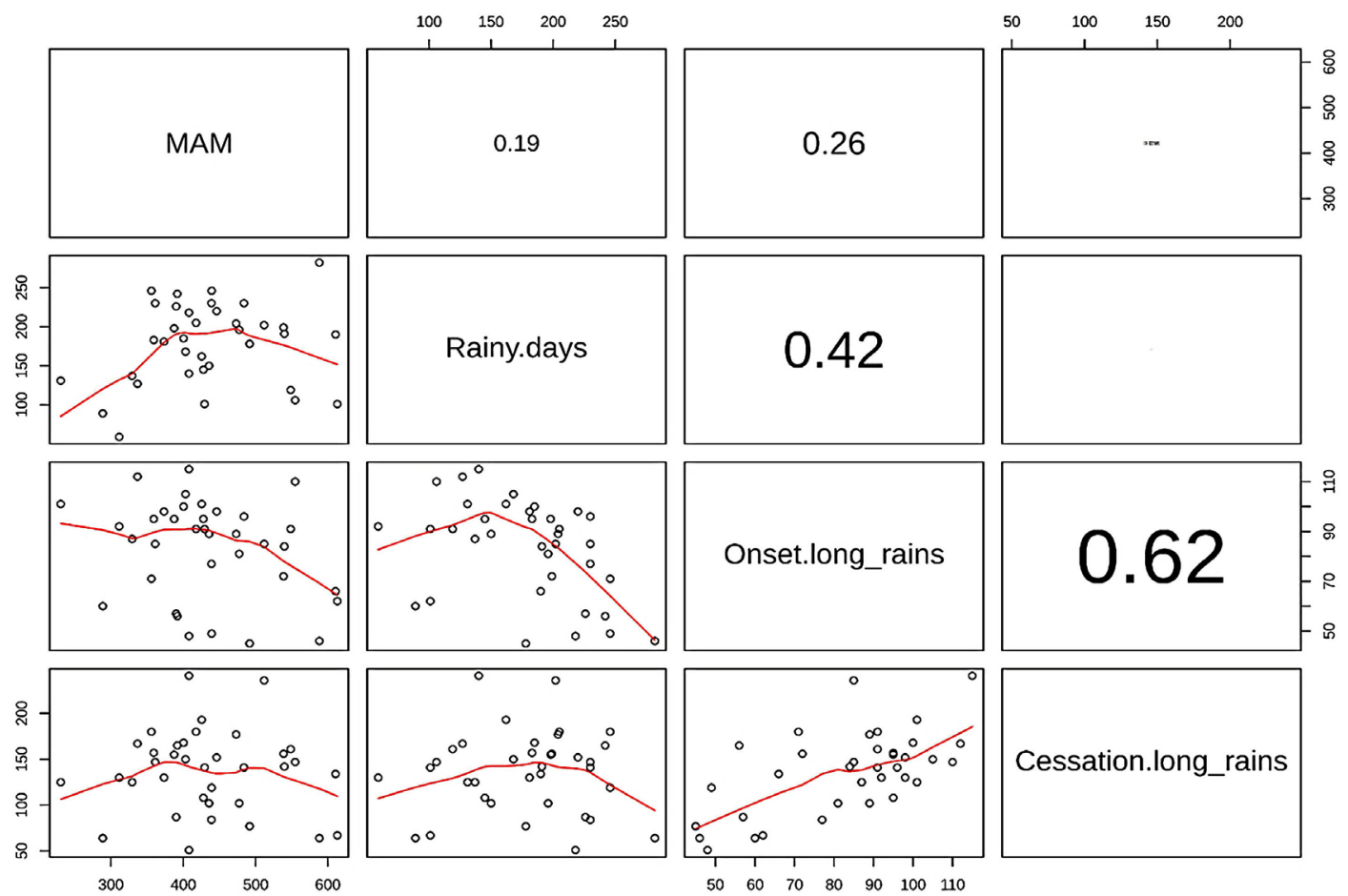

(a)

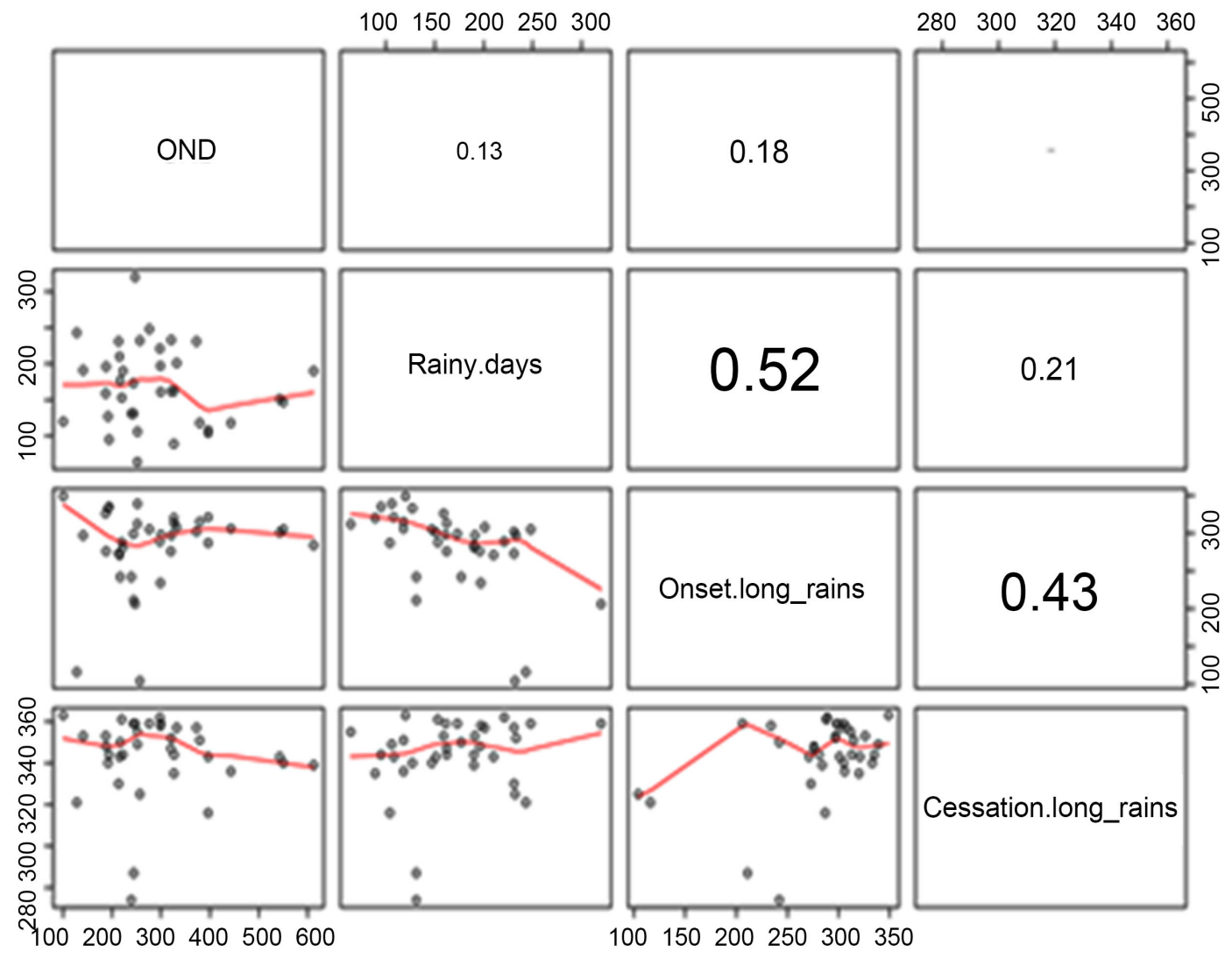

(b)

Figure 3. Paired plots showing correlations between MAM rainfall (a); other wet season parameters; rainy days, the onset of short rains and their cessations; and OND rainfall season (b). 

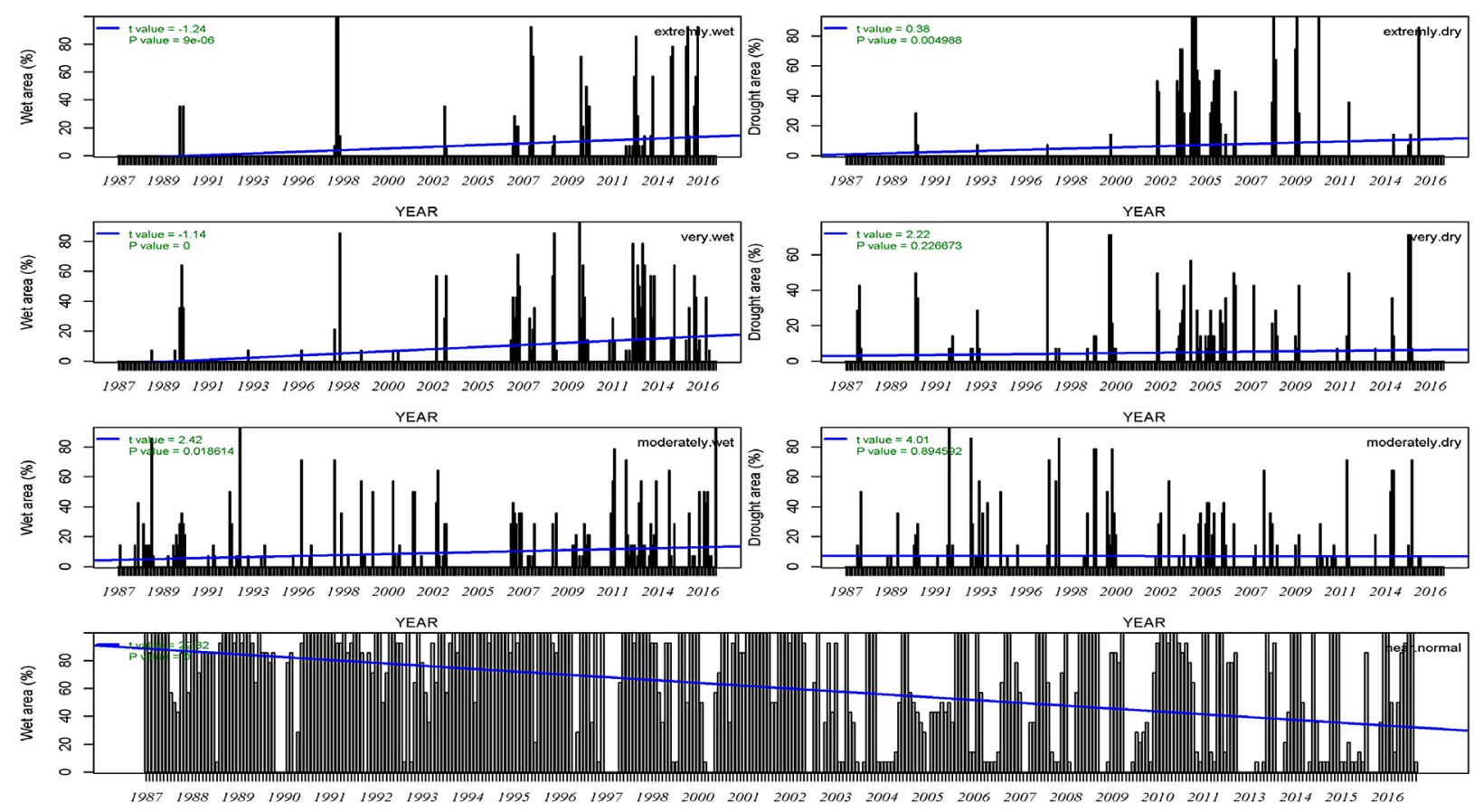

YEAR

(a)
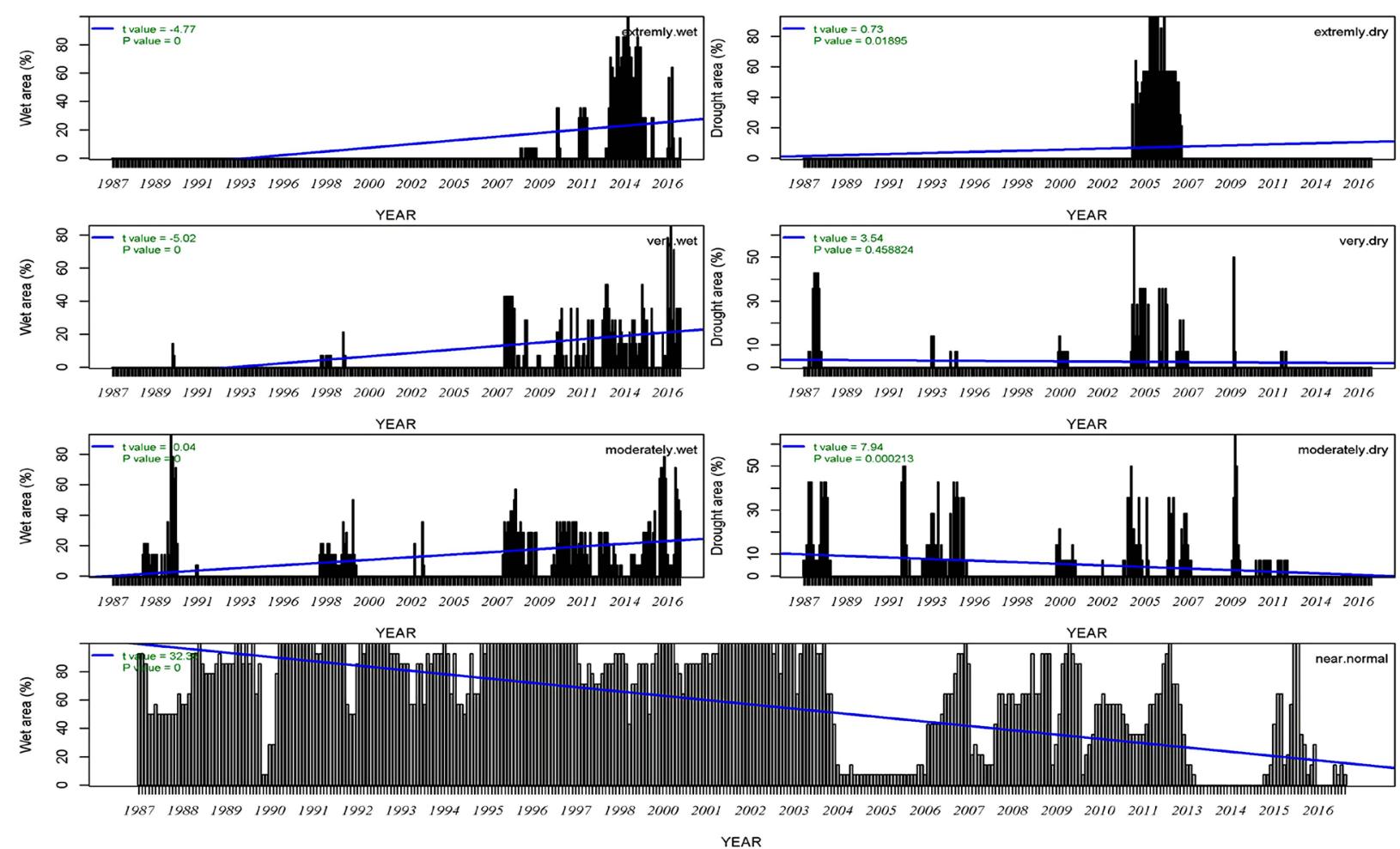

(b)

Figure 4. The 3-months scale SPI values (a) and 24-month scale SPI values (b) computed for all the Selected stations over the Lake Victoria Basin of Kenya.

rainfall for a period between 1957-2016. Other studies have established a negative trend in the basin. All the six weather stations under investigation, however, 


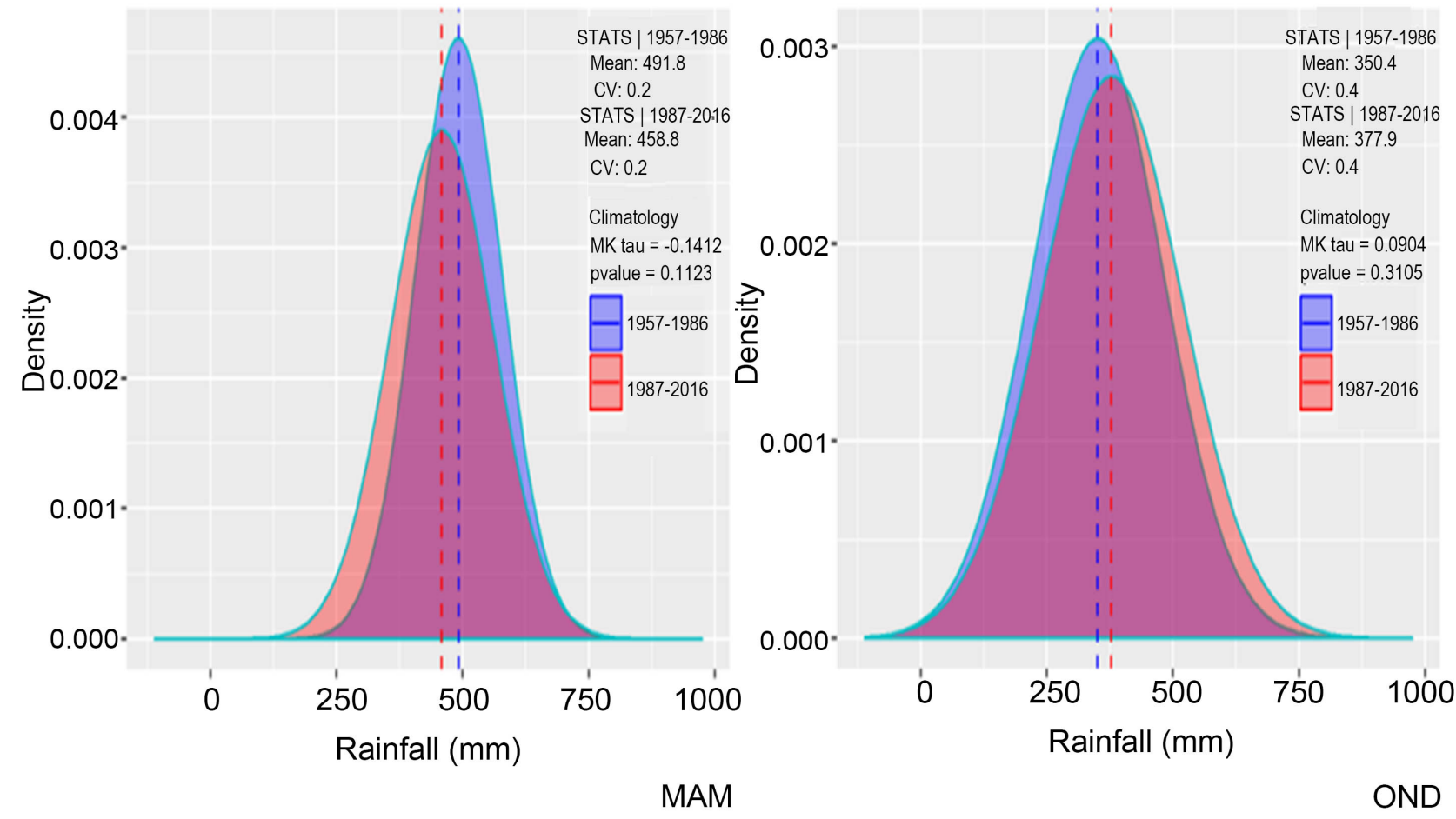

Figure 5. Distribution plots of rainfall over Muhuru Bay Hydromet Station. Two successive climate regimes are compared here: 1957 to1986 versus 987 to 2016 climate period.
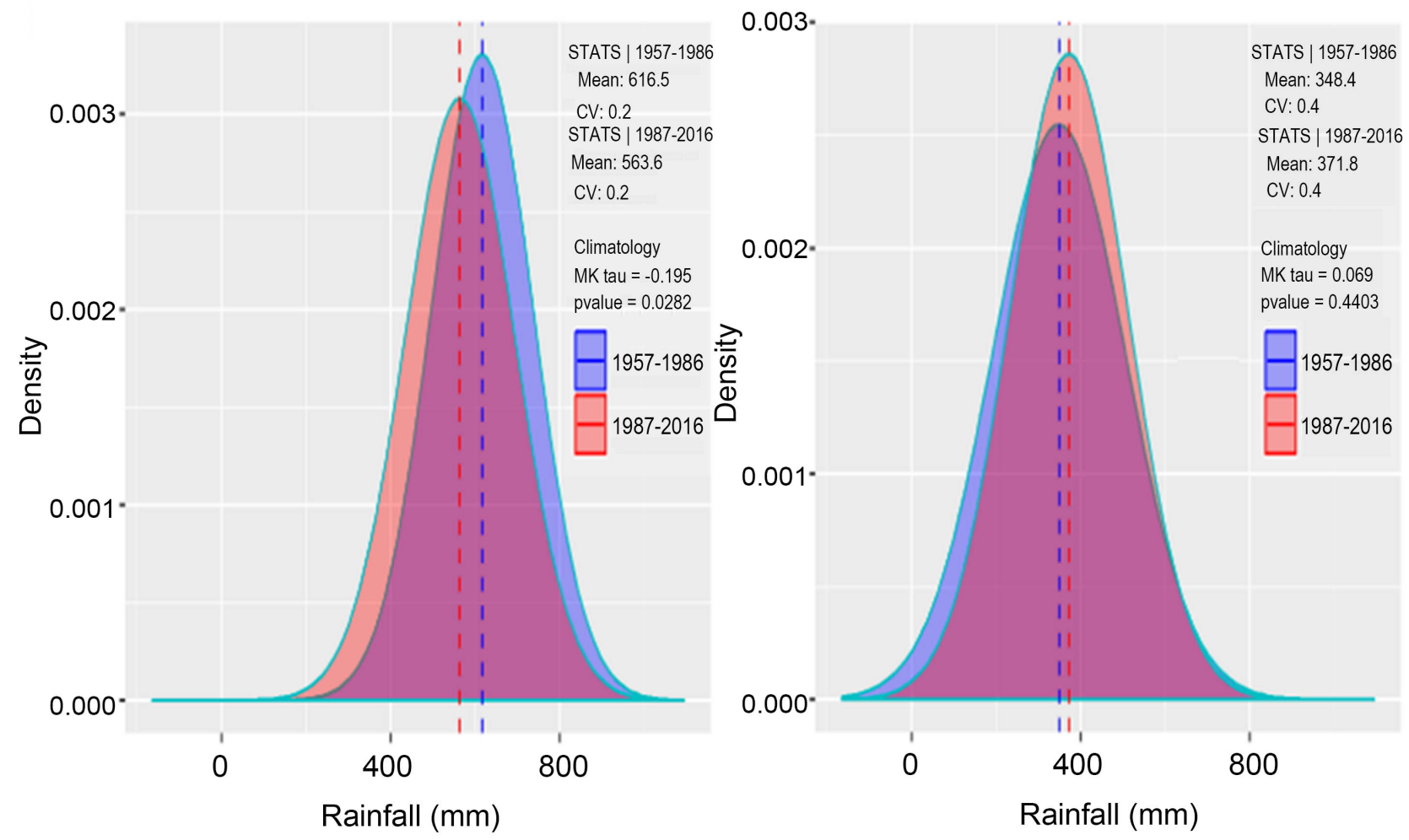

MAM

OND

Figure 6. Distribution plots of rainfall over Kericho Meteorological Station. Two successive climate regimes are compared here: 1957 to1986 versus 1987 to 2016 climate period. 


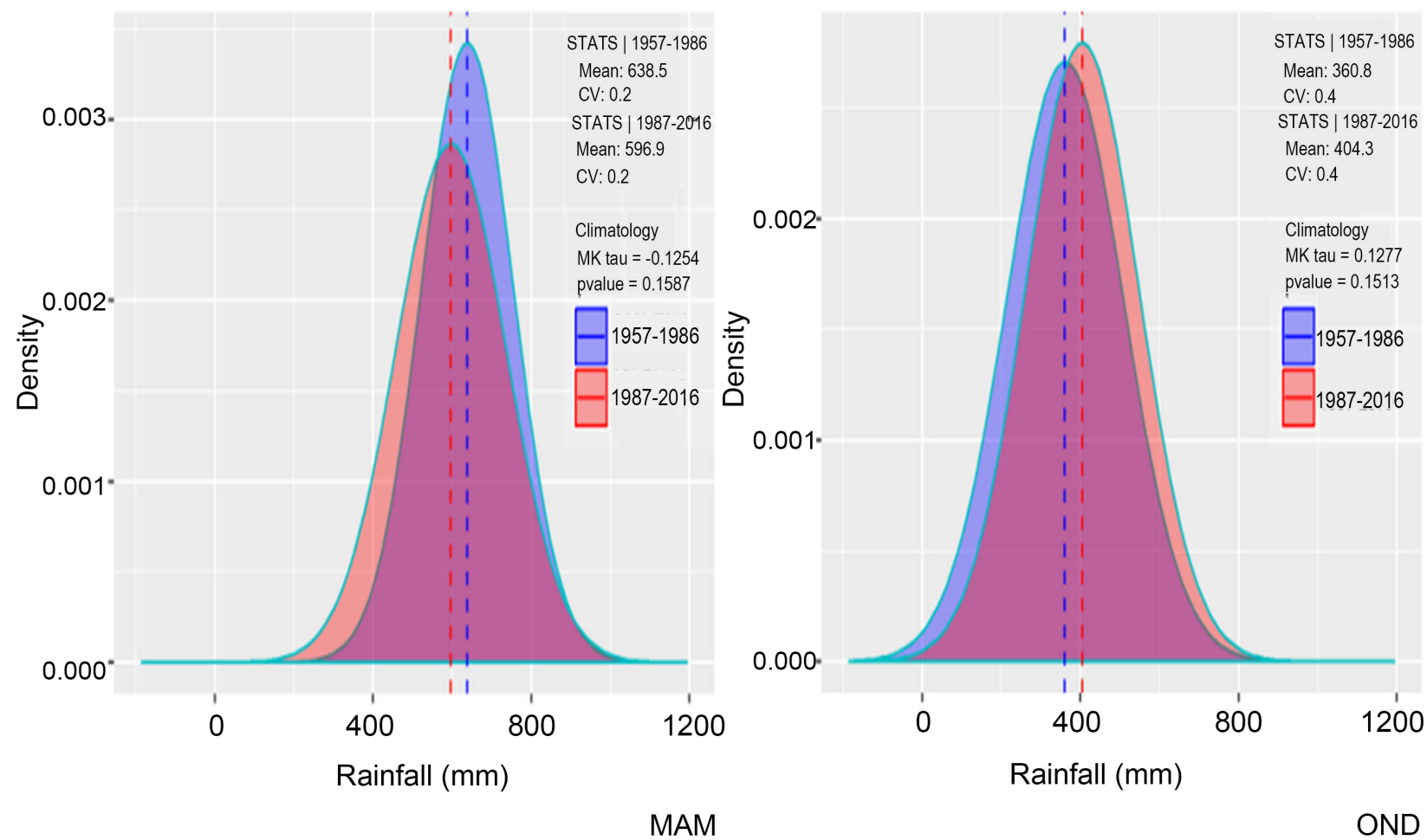

Figure 7. Distribution plots of rainfall over Kakamega Meteorological Station. Two successive climate regimes are compared here: 1957 to 1986 versus 1987 to 2016 climate period.

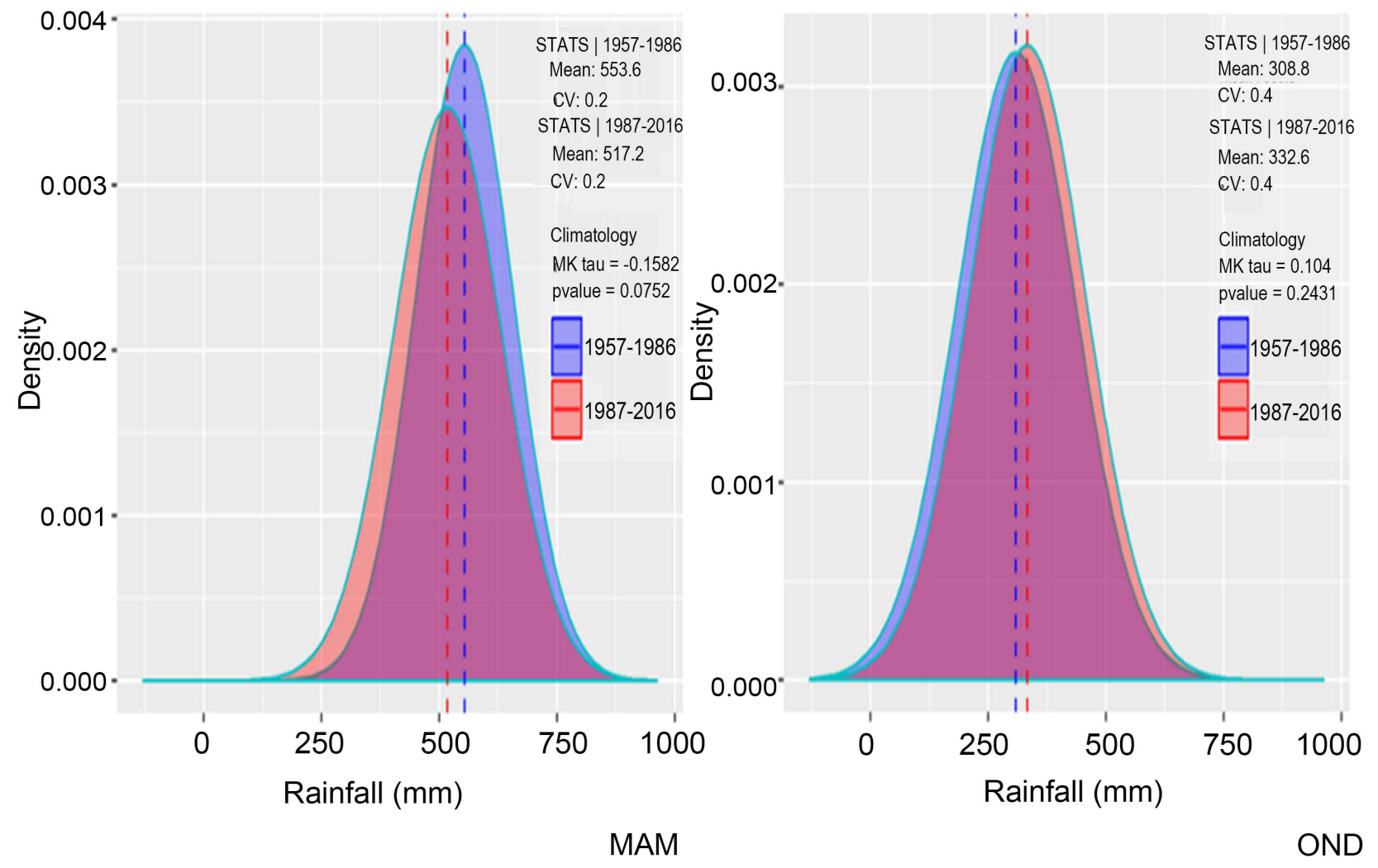

Figure 8. Distribution plots of rainfall over Kisumu Meteorological Station. Two successive climate regimes are compared here: 1957 to1986 versus 1987 to 2016 climate period. 


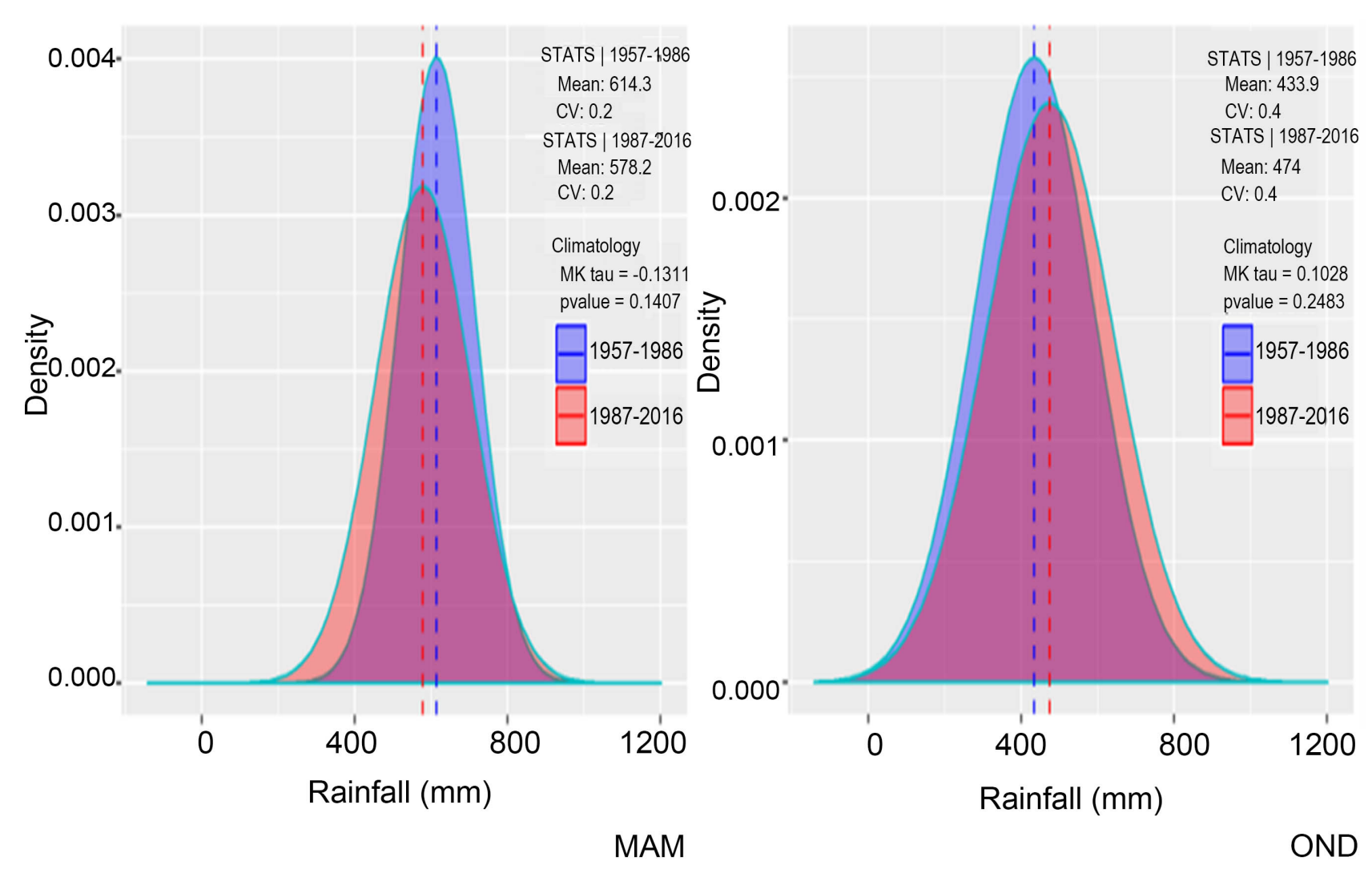

Figure 9. Distribution plots of rainfall over Kisii. Two successive climate regimes are compared here: 1957 to1986 versus 1987 to 2016 climate period.

recorded an increasing trend in OND (short rains). Kitale Meteorological Station (Figure 10) revealed that the trends in MAM seasonal rainfall had not significantly changed.

The study established at least $50 \%$ variability in the onsets of MAM rains within the estimated range of 50 and 100 Julian days which translated to mid-February and early April at the Kericho Meteorological Station, Kisumu Meteorological Station, and Sabatia Forest Station. The Muhuru Hydromet station however, exhibited at least $30 \%$ variability in OND rains cessations within the established range of about 100 to 200 Julian days (Figure 11). The result clearly demonstrated a decline in the number of rainy days.

The results also show a variability of at least $50 \%$ in the onsets of long rains within the estimated range of 50 and 100 Julian days at the Kisumu Meteorological Station and Kericho Meteorological Station, while other weather stations under investigation exhibited at least 30\% variability in the cessations of short rains within the established range of about 100 to 200 Julian days.

\section{Summary, Discussion and Conclusion}

The analysis of the LVB rainfall climatology revealed that the basin is relatively wet throughout the year. These results are consistent with an earlier study, which established a distinctive rainfall regime. The relative wetness has a spatial 

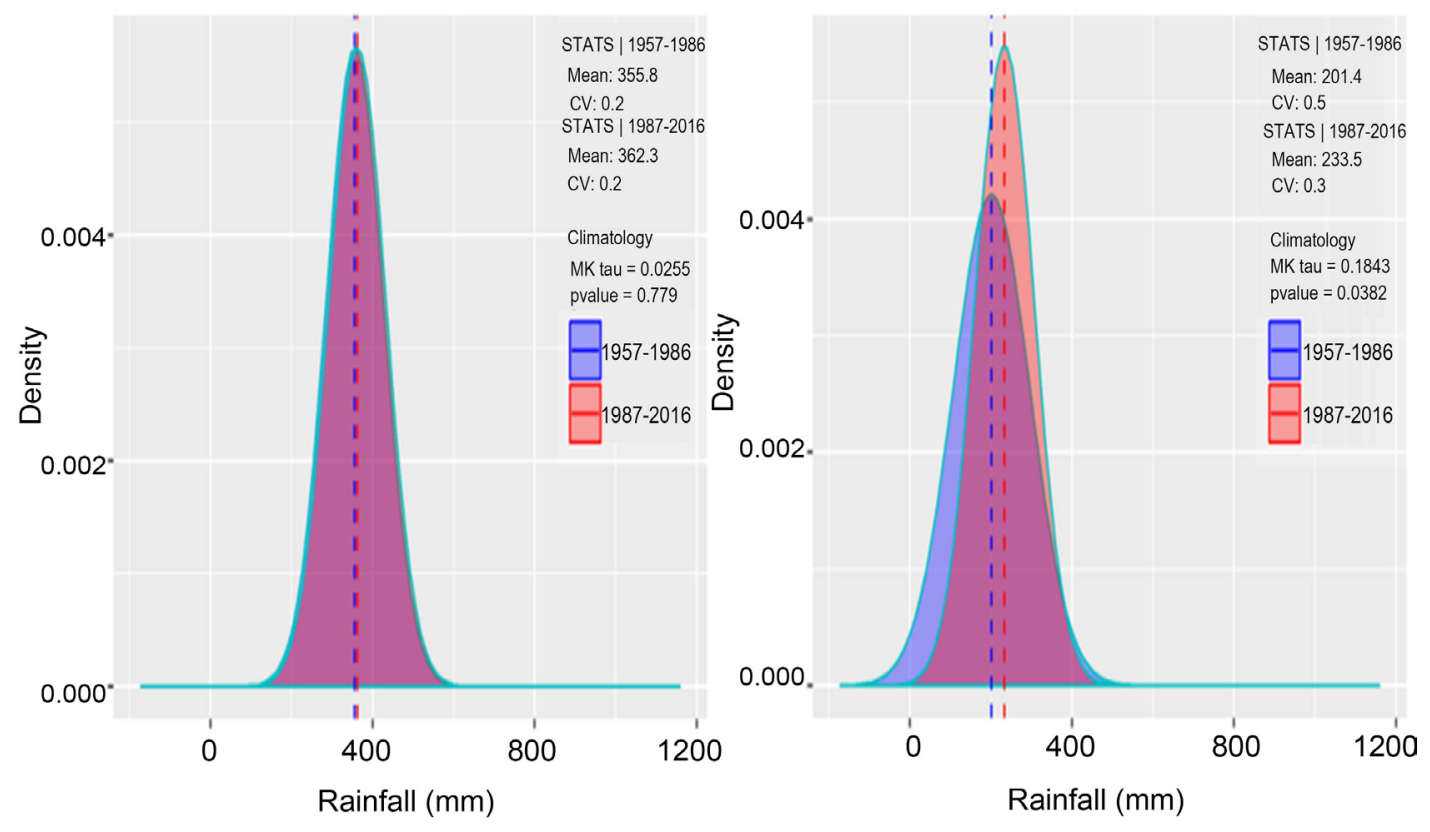

MAM

OND

Figure 10. Distribution plots of rainfall over Kitale Meteorological Station. Two successive climate regimes are compared here: 1957 to1986 versus 1987 to 2016 climate period.

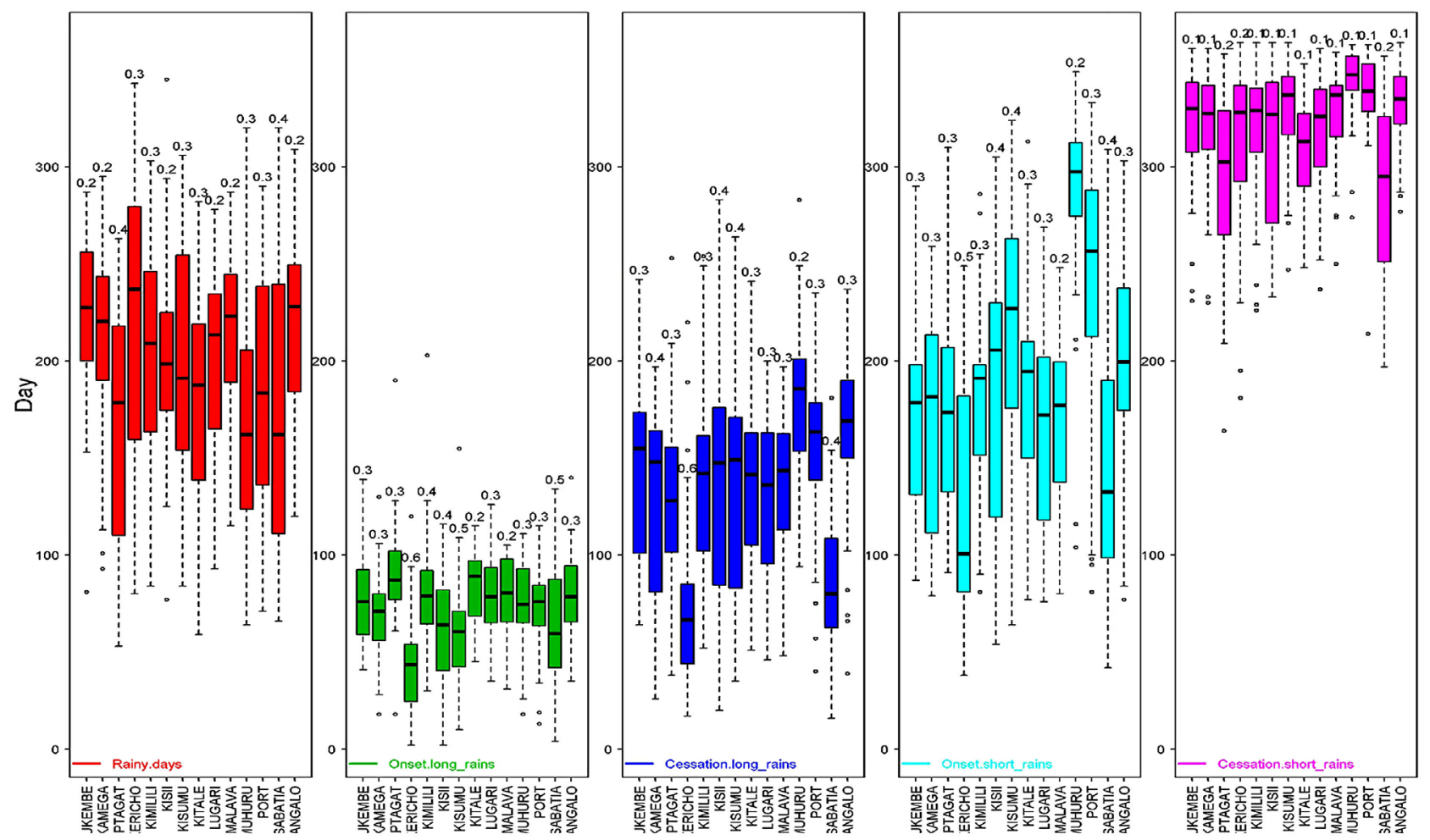

Figure 11. Boxplots showing variability in a number of rainy days, onset of long rains, cessation of long rains, onset and cessation of short rains from left to right in Julian days. Inserted are the coefficients of variability.

variation attributed to Lake Victoria's complex climate system that consists of undulating terrain, the extreme southward location of the Inter-Tropical Con- 
vergence Zone [33] and moisture influx due to its proximity to the lake [34]. Our results show Mar-May (MAM) and Oct-Dec (OND) rains being dominant. The results confirmed that the MAM and OND rains accounted for $42 \%$ and $25 \%$ of the total annual rains in the basin. The other two distinct rainfall regimes observed were the Jan-Feb (JB) rains which are affected by the southern Oscillation [35], and the Jun-Sep (JJAS) rains.

In this study, we established a declining trend in MAM (Long rains) and an increasing trend in the OND (short rains) rains in all the weather stations observed. The findings of this study could not verify an increase of about $2-3 \mathrm{~mm}$ annual rainfall over the Lake Victoria Basin [35]. The available literature, however, suggested that some models, Atmosphere-Ocean Global Circulation Models (AOGCMs), tended to overestimate rainfall seasons by showing a higher peak, which could likely reflect an increase in annual rainfall. On the other hand, (Nicholson, 1996 as cited Kizza et al. 2009) established a positive trend in MAM rains. This could be attributed to an overlap in the data source which had the years overlapping with this current study.

Rainfall variability has been observed over Africa between the years 1900-2000. Seasonal rainfall has also been established to be sensitive to El Niño climate variability [36]. An extremely wet category of rainfall which was recorded between 1997 and1998 coincided with the 1997 El Niño episode experienced in Eastern Africa. The extremely dry season experienced between the years 2002 and 2006 would be attributed to teleconnection of El Niño and La Niña in the region [37].

The onset and cessation of rainfall in LVB has been documented, as earlier discussed. An average onset occurred on March 25th and cessation on May 21st, with an onset inter-annual variability of the standard deviation of 14.5 days and cessation of 10.3 days respectively. An established variability of least $50 \%$ in the onsets of long rains within the estimated range of 50 and 100 Julian days indicated a delay of up to mid-February and early April and at least 30\% variability in the cessations of short rains within the established range of about 100 to 200 Julian days, which implies the rains occurred much earlier than expected. The numbers of rainy days have, therefore, reduced, which is likely to affect the general ecology of the region and impact soil moisture availability that supports human livelihood in the region. The relationship between the variation of rainfall amount and variability in onsets and cessations in the rainy seasons have been documented over the Modified Equatorial East Africa, which covered Kenya and Northeastern part of Tanzania. Further attempts to parameterize inter-annual variability of seasonal rainfall, the onset and cessation of daily rainfall data in three agro-ecological zones have been investigated [38].

\section{Conclusion}

The study has revealed that Lake Victoria experienced rainfall throughout the year, with two predominant rainfall seasons the MAM and OND seasonal rainfall. The MAMS rains have declined while the OND rains have increased. The 
onset and cessations of this seasonal rainfall have been observed to be varying from the Julian days over the year, with at least $50 \%$ of the variability being exhibited for the onset of March-May rains, hence, occurring later in the month and, at least, $30 \%$ for cessations of OND rains, occurring earlier in the month in a range of about 100 to 200 Julian days. Proper monitoring of ecology is, therefore, needed, especially where rainfall and moisture content is critical. Additional caution is also necessary when planning human activities that rely on rainfall as their main source of moisture. This work shows that the 3-month scale for Standardized Precipitation Index can better determine the wetness condition compared to the 12-month scale, which suppressed the extreme wet conditions such as ENSO and El Niño episode. This study was mainly interested in establishing the general rainfall trend over the Lake Victoria Basin of Kenya. Additional studies are needed to assess the impact of rainfall variability on the entire ecosystem in the basin.

\section{Conflicts of Interest}

The authors declare no conflicts of interest regarding the publication of this paper.

\section{References}

[1] A Müller, C., Cramer, W., Hare, W.L. and Lotze-Campen, H. (2011) Climate Change Risks for African Agriculture. Proceedings of the National Academy of Sciences, 108, 4313-4315. https://doi.org/10.1073/pnas.1015078108

[2] Awange, J.L., Anyah, R., Agola, N., Forootan, E. and Omondi, P. (2013) Potential Impacts of Climate and Environmental Change on the Stored Water of Lake Victoria Basin and Economic Implications. Water Resources Research, 49, 8160-8173. https://doi.org/10.1002/2013WR014350

[3] Shongwe, M.E., van Oldenborgh, G.J., van den Hurk, B. and van Aalst, M. (2011) Projected Changes in Mean and Extreme Precipitation in Africa under Global Warming. Part II: East Africa. Journal of Climate, 24, 3718-3733. https://doi.org/10.1175/2010JCLI2883.1

[4] Tennant, W.J. and Hewitson, B.C. (2002) Intra-Seasonal Rainfall Characteristics and Their Importance to the Seasonal Prediction Problem. International Journal of Climatology: A Journal of the Royal Meteorological Society, 22, 1033-1048. https://doi.org/10.1002/joc.778

[5] Boko, M., Niang, I., Nyong, A., Vogel, A., Githeko, A., Medany, M., Yanda, P.Z., et al. (2018) Africa Climate Change 2007: Impacts, Adaptation and Vulnerability: Contribution of Working Group II to the Fourth Assessment Report of the Intergovernmental Panel on Climate Change.

[6] Lyon, B. and DeWitt, D.G. (2012) A Recent and Abrupt Decline in the East African Long Rains. Geophysical Research Letters, 39, L02702. https://doi.org/10.1029/2011GL050337

[7] Thornton, P.K., Jones, P.G., Alagarswamy, G., Andresen, J. and Herrero, M. (2010) Adapting to Climate Change: Agricultural System and Household Impacts in East Africa. Agricultural Systems, 103, 73-82. https://doi.org/10.1016/j.agsy.2009.09.003

[8] Schlesinger, M.E. (2012) Physically-Based Modelling and Simulation of Climate and 
Climatic Change. Volume 243, Springer Science \& Business Media, New York.

[9] Otieno, G., Mutemi, J.N., Opijah, F.J., et al. (2020) The Sensitivity of Rainfall Characteristics to Cumulus Parameterization Schemes from a WRF Model. Part I: A Case Study Over East Africa During Wet Years. Pure and Applied Geophysics, 177, 1095-1110. https://doi.org/10.1007/s00024-019-02293-2

[10] Mugume, I., Waiswa, D., Mesquita, M.D.S., Reuder, J., Basalirwa, C., Bamutaze, Y., et al. (2017) Assessing the Performance of WRF Model in Simulating Rainfall over Western Uganda. Journal of Climatology and Weather Forecasting, 5, 197.

[11] Marteau, R., Richard, Y., Pohl, B., Smith, C.C. and Castel, T. (2015) High-Resolution Rainfall Variability Simulated by the WRF RCM: Application to Eastern France. Climate Dynamics, 44, 1093-1107. https://doi.org/10.1007/s00382-014-2125-5

[12] Gbode, I.E., Dudhia, J., Ogunjobi, K.O. and Ajayi, V.O. (2018) Sensitivity of Different Physics Schemes in the WRF Model during a West African Monsoon Regime. Theoretical and Applied Climatology, 136, 1-19. https://doi.org/10.1007/s00704-018-2538-x

[13] Nicholson, S.E. (1996) A Review of Climate Dynamics and Climate Variability in Eastern Africa. In: The Limnology, Climatology and Paleoclimatology of the East African Lakes, Gordon and Breach Publishers, Amsterdam.

[14] Hulme, M., Doherty, R., Ngara, T., New, M. and Lister, D. (2001) African Climate Change: 1900-2100. Climate Research, 17, 145-168. https://doi.org/10.3354/cr017145

[15] Kendall, R.L. (1969) An Ecological History of the Lake Victoria Basin. Ecological Monographs, 39, 121-176. https://doi.org/10.2307/1950740

[16] Kizza, M., Rodhe, A., Xu, C.Y., Ntale, H.K. and Halldin, S. (2009) Temporal Rainfall Variability in the Lake Victoria Basin in East Africa during the Twentieth Century. Theoretical and Applied Climatology, 98, 119-135. https://doi.org/10.1007/s00704-008-0093-6

[17] Sylla, M.B., Giorgi, F., Coppola, E. and Mariotti, L. (2013) Uncertainties in Daily Rainfall over Africa: Assessment of Gridded Observation Products and Evaluation of a Regional Climate Model Simulation. International Journal of Climatology, 33, 1805-1817. https://doi.org/10.1002/joc.3551

[18] Anyah, R.O. and Qiu, W. (2012) Characteristic 20th and 21st Century Precipitation and Temperature Patterns and Changes over the Greater Horn of Africa. International Journal of Climatology, 32, 347-363. https://doi.org/10.1002/joc.2270

[19] Indeje, M., Semazzi, F.H.M, Ogallo, L.J. (2000) ENSO Signals in East African Rainfall Seasons. International Journal of Climatology, 20, 19-46. https://doi.org/10.1002/(SICI)1097-0088(200001)20:1<19::AID-JOC449>3.0.CO;2-0

[20] Awange, J.L., Aluoch, J., Ogallo, L.A., Omulo, M. and Omondi, P. (2007) Frequency and Severity of Drought in the Lake Victoria Region (Kenya) and Its Effects on Food Security. Climate Research, 33, 135-142. https://doi.org/10.3354/cr033135

[21] Odada, E.O., Ochola, W.O. and Olago, D.O. (2009) Drivers of Ecosystem Change and Their Impacts on Human Well-Being in Lake Victoria Basin. African Journal of Ecology, 47, 46-54. https://doi.org/10.1111/j.1365-2028.2008.01049.x

[22] Williams, A.P., Funk, C., Michaelsen, J., Rauscher, S.A., Robertson, I., Wils, T.H., Koprowski, M., Eshetu, Z. and Loader, N.J. (2012) Recent Summer Precipitation Trends in the Greater Horn of Africa and the Emerging Role of Indian Ocean Sea Surface Temperature. Climate Dynamics, 39, 2307-2328. 
https://doi.org/10.1007/s00382-011-1222-y

[23] Intergovernmental Panel on Climate Change (2007) Climate Change 2007: The Physical Science Basis: Contribution of Working Group 1 to the Fourth Assessment Report of the IPCC. Cambridge University Press, Cambridge.

[24] Intergovernmental Panel on Climate Change (2014) Summary for Policymakers. In: Climate Change 2014: Impacts, Adaptation, and Vulnerability. Part A: Global and Sectoral Aspects. Contribution of Working Group II to the Fifth Assessment Report of the Intergovernmental Panel on Climate Change, Cambridge University Press, Cambridge, United Kingdom, and New York.

[25] United Nations Environmental Programme (2006) Lake Victoria Basin Environment Outlook: Environment and Development. UNEP, Nairobi.

[26] Peterson, T.C., Easterling, D.R., Karl, T.R., Groisman, P., Nicholls, N., Plummer, N., Torok, S., Auer, I., Boehm, R., Gullett, D. and Vincent, L. (1998) Homogeneity Adjustments of in Situ Atmospheric Climate Data: A Review. International Journal of Climatology: A Journal of the Royal Meteorological Society, 18, 1493-1517. https://doi.org/10.1002/(SICI)1097-0088(19981115)18:13<1493::AID-JOC329>3.0.C $\underline{\mathrm{O} ; 2-\mathrm{T}}$

[27] Zhang, X., Zwiers, F.W. and Hegerl, G. (2009) The Influences of Data Precision on the Calculation of Temperature Percentile Indices. International Journal of Climatology: A Journal of the Royal Meteorological Society, 29, 321-327. https://doi.org/10.1002/joc.1738

[28] R Core Team (2018) R: A Language and Environment for Statistical Computing. R Foundation for Statistical Computing, Vienna, Austria. https://www.R-project.org/

[29] World Meteorological Organization (2012) Standardized Precipitation Index User Guide, (WMO-No. 1090). World Meteorological Organization, Geneva, Switzerland.

[30] Liebmann, B., Bladé, I., Kiladis, G.N., Carvalho, L.M., Senay, G.B., Allured, D., Leroux, S. and Funk, C. (2012) Seasonality of African Precipitation from 1996 to 2009. Journal of Climate, 25, 4304-4322. https://doi.org/10.1175/JCLI-D-11-00157.1

[31] Ogallo, L.A., Omondi, P., Ouma, G. and Wayumba, G. (2018) Climate Change Projections and the Associated Potential Impacts for Somalia. American Journal of Climate Change, 7, 153. https://doi.org/10.4236/ajcc.2018.72011

[32] Mbungu, W., Ntegeka, V., Kahimba, F.C., Taye, M. and Willems, P. (2012) Temporal and Spatial Variations in Hydro-Climatic Extremes in the Lake Victoria Basin. Physics and Chemistry of the Earth, Parts A/B/C, 50, 24-33. https://doi.org/10.1016/j.pce.2012.09.002

[33] Camberlain, P., Janicot, S. and Poccard, I. (2001) Seasonality and Atmospheric Dynamics of the Teleconnection between African Rainfall and Tropical Sea-Surface Temperature: Atlantic vs. ENSO. International Journal of Climatology, 21, 973-1005. https://doi.org/10.1002/joc.673

[34] Indeje, M., Semazzi, F.H.M. and Ogallo, L.J. (2000) ENSO Signals in East African Rainfall Seasons. International Journal of Climatology, 20, 19-46. https://doi.org/10.1002/(SICI)1097-0088(200001)20:1<19::AID-JOC449>3.0.CO;2-0

[35] Ongoma, V., Chen, H. and Omony, G.W. (2018) Variability of Extreme Weather Events over the Equatorial East Africa: A Case Study of Rainfall in Kenya and Uganda. Theoretical and Applied Climatology, 131, 295-308.

https://doi.org/10.1007/s00704-016-1973-9 
[36] Hulme, M. (1992) Rainfall Changes in Africa: 1931-1960 to 1961-1990. International Journal of Climatology, 12, 685-699. https://doi.org/10.1002/joc.3370120703

[37] Anyamba, A., Tucker, C.J. and Mahoney, R. (2002) From El Niño to La Niña: Vegetation Response Patterns over East and Southern Africa during the 1997-2000 Period. Journal of Climate, 15, 3096-3103.

https://doi.org/10.1175/1520-0442(2002)015<3096:FENOTL>2.0.CO;2

[38] Camberlin, P. and Okoola, R. (2003) The Onset and Cessation of the "Long Rains" in Eastern Africa and Their Inter-Annual Variability. Theoretical and Applied Climatology, 75, 43-54. https://doi.org/10.1007/s00704-002-0721-5 